\title{
Thyroid Hormone Inhibition of the Prolactin Response
}

\section{to Thyrotropin-Releasing Hormone}

\author{
Peter J. Snyder, Laurence S. Jacobs, Robert D. Utiger, and \\ William H. Daughaday \\ From the Endocrine Section, Department of Medicine, University of Pennsylvania, \\ Philadelphia, Pennsylvania 19104 and Metabolism Division, Department of \\ Medicine, Washington University School of Medicine, St. Louis, Missouri, 63110
}

A в S т R A C T The influence of serum triiodothyronine $\left(T_{3}\right)$ and thyroxine $\left(T_{4}\right)$ concentrations on the release of prolactin in man was studied by determining the prolactin response to synthetic thyrotropin-releasing hormone (TRH) in hypothyroid and hyperthyroid patients before and after correction of their serum thyroid hormone abnormalities. The maximum increment in serum prolactin above the basal level (maximum $\Delta$ prolactin) was used as the index of response to TRH.

In 12 patients with primary hypothyroidism, the maximum $\Delta$ prolactin in response to TRH fell from 100.5 \pm $29.1 \mathrm{ng} / \mathrm{ml}$ (mean \pm SEM) before treatment to $36.1 \pm 6.0$ $\mathrm{ng} / \mathrm{ml}(P<0.01)$ during the 4 th $w \mathrm{k}$ of treatment with $30 \mu \mathrm{g} \mathrm{T}_{3}+120 \mu \mathrm{g} \mathrm{T}_{4}$ daily. The mean serum $\mathrm{T}_{3}$ level increased from $57 \pm 8$ to $138 \pm 10 \mathrm{ng} / 100 \mathrm{ml}$, and the mean serum $\mathrm{T}_{4}$ level increased from $3.0 \pm 0.4$ to $7.2 \pm 0.4$ $\mu \mathrm{g} / 100 \mathrm{ml}$ during this treatment. In eight normal subjects the maximum $\Delta$ prolactin in response to $\mathrm{TRH}$ was not significantly different during the 4 th $w \mathrm{k}$ of treatment with $30 \mu \mathrm{g} \mathrm{T}_{3}+120 \mu \mathrm{g} \mathrm{T}_{4}$ daily from the response before treatment. In 10 patients with hyperthyroidism, the maximum $\Delta$ prolactin in response to $\mathrm{TRH}$ increased from $14.2 \pm 2.9 \mathrm{ng} / \mathrm{ml}$ before treatment to $46.9 \pm 6.7 \mathrm{ng} / \mathrm{ml}$ $(P<0.001)$ during antithyroid treatment. The mean serum $\mathrm{T}_{3}$ level fell from $313 \pm 47$ to $90 \pm 8 \mathrm{ng} / 100 \mathrm{ml}$, and the mean serum $T_{*}$ level fell from $20.8 \pm 2.5$ to $6.8 \pm$ $0.6 \mu \mathrm{g} / 100 \mathrm{ml}$ during this treatment.

These results show that changes from normal serum levels of $T_{3}$ and $T_{4}$ are associated with changes in prolactin responses to $\mathrm{TRH}$; subnormal serum levels of $\mathrm{T}_{3}$ and $\mathrm{T}_{4}$ increase $\mathrm{TRH}$-induced prolactin release,

Dr. Jacobs is a Research Career Development Awardee of the U. S. Public Health Service (1KO4 AM-70521-01).

Received for publication 5 February 1973 and in revised form 17 April 1973. whereas substantially higher than normal serum levels of $T_{3}$ and $T_{4}$ inhibit this release.

\section{INTRODUCTION}

Thyrotropin-releasing hormone (TRH) has been shown to be at least as potent and rapid a stimulus of prolactin release (1-3) as of thyrotropin ( $\mathrm{TSH})$ release in normal man. The TSH release stimulated by the administration of synthetic TRH is exquisitely sensitive to inhibition by thyroid hormones (4). The objective of this study was to determine whether prolactin release paralleled TSH release not only in being stimulated by TRH but also in this stimulus being inhibited by thyroid hormones. Toward this end, the prolactin response to synthetic TRH was determined in patients with primary hypothyroidism before and after they had been made euthyroid with thyroid hormone medication, and the prolactin response to TRH was determined in hyperthyroid patients before and after they had been made euthyroid with antithyroid medication.

\section{METHODS}

Subjects and design. All subjects gave informed, written consent to receive TRH. No subject was taking any medication known to affect serum prolactin levels or any medication known to affect thyroid hormone economy, with the exception of those medications, described below, that were given as part of the study. The technique of administration of TRH (Abbott Laboratories, North Chicago, IIl.) and sampling of blood has been described (5). The only dose of TRH used was $400 \mu \mathrm{g}$, given as an i.v. bolus.

Because of the wide range of the prolactin response to $\mathrm{TRH}$ in normal subjects, especially in those over $40-\mathrm{yr}$ old (6), the effect of varying the serum concentrations of thyroid hormones was tested exclusively by having each subject, whether initially hypothyroid, euthyroid, or hyper- 
thyroid, serve as his own control. Also, to attempt to limit the influence on prolactin release to the thyroid hormone levels, no patients with hypothyroidism or hyperthyroidism due to pituitary or hypothalamic disease were studied.

12 patients ( 7 females, 5 males; ages 28-67) were diagnosed as having primary hypothyroidism on the basis of both subnormal thyroxine $\left(\mathrm{T}_{4}\right)$ and supranormal TSH concentrations. None had galactorrhea. Each hypothyroid patient's serum prolactin response to i.v. TRH was determined before any thyroid hormone treatment and again during the 4th wk of the daily administration of a synthetic combination of $30 \mu \mathrm{g}$ triiodothyronine $\left(T_{3}\right)+120$ $\mu \mathrm{g} \mathrm{T}_{\mathbf{4}}$.

Eight normal subjects (all males, ages 21-29) were confirmed as being euthyroid on the basis of normal serum $T_{3}$, $T_{4}$, and TSH concentrations. Each euthyroid subject's prolactin response to $\mathrm{TRH}$ was also determined before any thyroid hormone treatment and again during the 4th wk of the daily administration of $30 \mu \mathrm{g} \mathrm{T}_{3}+120 \mu \mathrm{g} \mathrm{T}_{4}$. These eight subjects are the same ones in whom the inhibition of $\mathrm{TRH}$-induced $\mathrm{TSH}$ release by $\mathrm{T}_{3}+\mathrm{T}_{4}$ administration was reported (4).

10 patients ( 9 females, 1 male; ages 16-56) with diffuse thyroid enlargement were diagnosed as having hyperthyroidism on the basis of elevated serum $T_{3}$ and $T_{4}$ levels, low-normal serum $\mathrm{TSH}$ levels, and $\mathrm{T}_{3}$ resin uptake ratios that demonstrated no excessive serum protein binding of thyroid hormones. Each hyperthyroid patient's prolactin response to $\mathrm{TRH}$ was determined before any antithyroid treatment and again after the serum $T_{3}$ and $T_{4}$ levels had been lowered by antithyroid treatment. Eight patients were treated with varying doses of methimazole, and three patients were treated with radioactive iodide. The second TRH test was performed as soon as the patient was clinically and chemically euthyroid, which was from 1 to 8 mo after the initiation of antithyroid treatment.

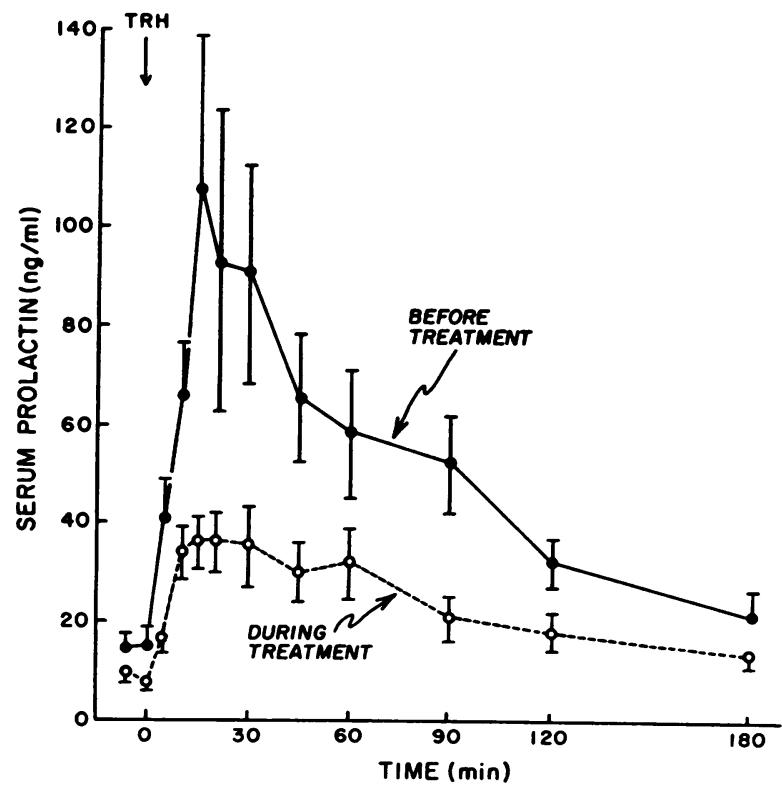

FIGURE 1 Serum prolactin responses to i.v. TRH before and during thyroid hormone treatment $\left(30 \mu \mathrm{g} \mathrm{T}_{3}+120 \mu \mathrm{g}\right.$ $\mathrm{T}$, daily for 3-4 wk) in 12 patients with primary hypothyroidism. Means are given \pm SEM.

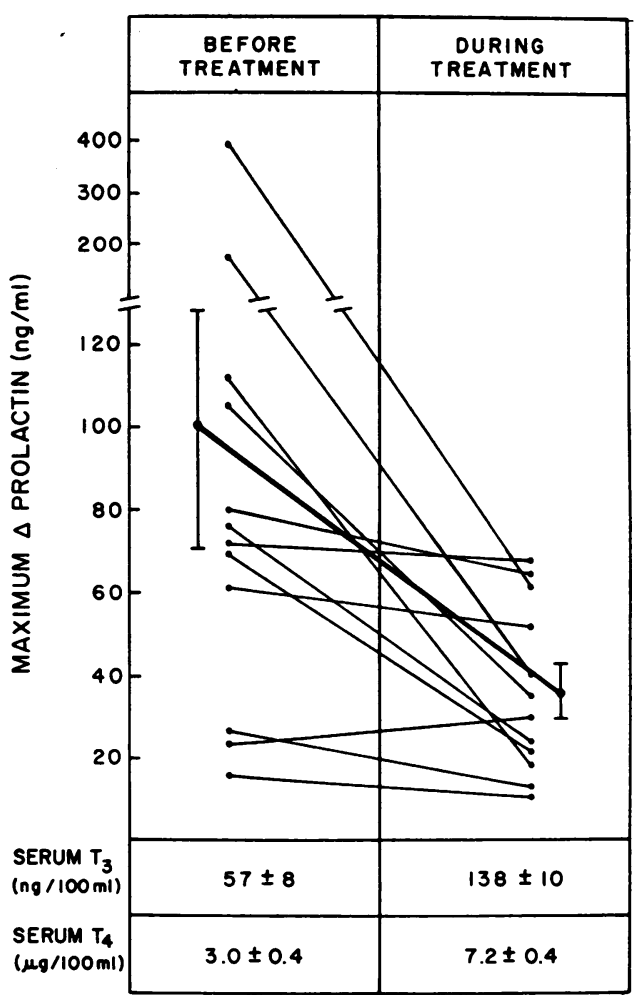

FIGURE 2 Effect of thyroid hormone treatment (30 $\mu \mathrm{g} \mathrm{T}_{8}$ $+120 \mu \mathrm{g} \mathrm{T}$, daily for 3-4 wk) on the individual maximum $\Delta$ prolactin responses to i.v. TRH in 12 patients with primary hypothyroidism. The heavy line connects the mean ( \pm SEM) maximum $\Delta$ prolactin responses. The mean serum $T_{8}$ and $\mathrm{T}_{4}$ levels $( \pm \mathrm{SEM})$ before and during treatment are also shown. The normal range of serum $T_{3}$ is $70-150 \mathrm{ng} / 100 \mathrm{ml}$, and, of $T_{\star}$ is $5-11 \mu \mathrm{g} / 100 \mathrm{ml}$.

Analyses. Serum $\mathrm{T}_{3}(7), \mathrm{TSH}$ (8), and prolactin (9) were measured by immunoassay. The standard used in the prolactin immunoassay was a serum rich in prolactin from a patient with a prolactin-secreting pituitary tumor. This serum was standardized against two other sera that had been bioassayed (9) and against highly purified human prolactin (10). The maximum increment in serum prolactin above the basal level (maximum $\Delta$ prolactin) after TRH administration was used as the index of prolactin response to $T R H$. Serum $T_{4}$ was measured by competitive protein binding (11). Normal values for these assays in our laboratories are as follows: serum $\mathrm{T}_{\mathbf{3}}, 70-150 \mathrm{ng} / 100 \mathrm{ml}$; serum $\mathrm{T}_{4}, 5-11 \mu \mathrm{g} / 100 \mathrm{ml}$; serum $\mathrm{TSH},<2-8 \mu \mathrm{U} / \mathrm{ml}$; and serum prolactin, $<2-25 \mathrm{ng} / \mathrm{ml}$. All samples for these assays from any one subject were analyzed in the same assay run. The paired $t$ test (12) and the Wilcoxon signed rank test (13) were used to assess statistical significance. When not stated otherwise in the Results section, the paired $t$ test was used. The correlation coefficient (14) was used to determine the degree of correlation between thyroid hormone levels and prolactin response.

\section{RESULTS}

Hypothyroid patients. Fig. 1 shows the mean serum prolactin response of 12 patients with primary hypothy- 


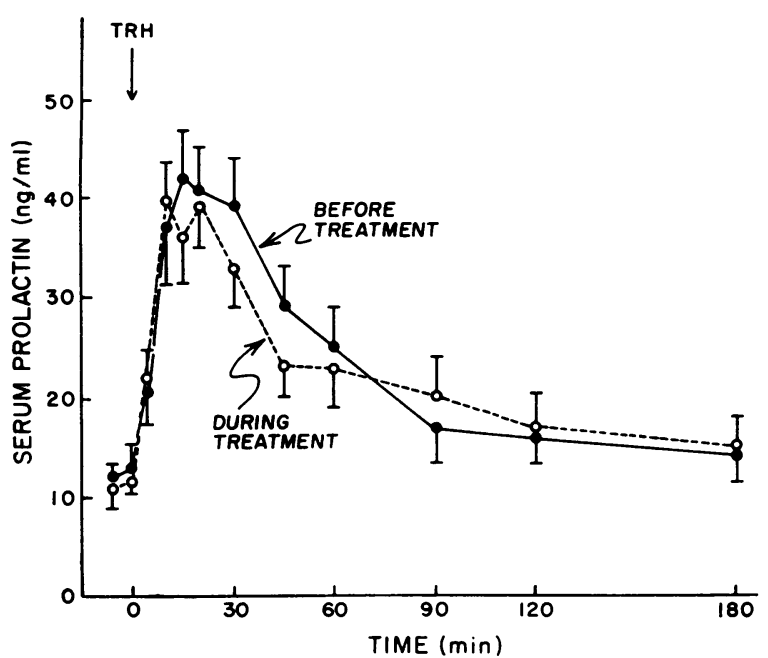

Figure 3 Serum prolactin responses to i.v. TRH before and during thyroid hormone treatment $\left(30 \mu \mathrm{g} \mathrm{T}_{3}+120 \mu \mathrm{g}\right.$ $T_{4}$ daily for 3-4 wk) in eight normal subjects. Means are given \pm SEM.

roidism to the i.v. injection of $400 \mu \mathrm{g}$ TRH before treatment and during the 4 th $\mathrm{wk}$ of treatment with replacement doses of thyroid hormone, $30 \mu \mathrm{g} \mathrm{T}_{3}+120 \mu \mathrm{g} \mathrm{T}_{4}$ once daily. Before thyroid hormone replacement the serum prolactin was $15.0 \pm 3.4 \mathrm{ng} / \mathrm{ml}$ (mean $\pm \mathrm{SEM}$ ) before TRH administration and reached a peak level of $107.5 \pm 30.0 \mathrm{ng} / \mathrm{ml} 15 \mathrm{~min}$ after TRH. During the 4th wk of treatment, the mean serum prolactin was $9.1 \pm 1.4$ $\mathrm{ng} / \mathrm{ml}$ before $\mathrm{TRH}$ and reached a peak of $36.6 \pm 6.5 \mathrm{ng} /$ $\mathrm{ml} 20 \mathrm{~min}$ after TRH. The fall in the mean pre-TRH prolactin level was not statistically significant.

The fall in the prolactin response to TRH after thyroid hormone replacement was examined in greater detail by comparing the maximum $\Delta$ prolactin of each hypothyroid patient before and during thyroid hormone replacement, as shown in Fig. 2. The maximum $\Delta$ prolactin was lowered by thyroid hormone replacement in 11 of the 12 patients, and the mean maximum $\Delta$ prolactin fell from $100.5 \pm 29.1 \mathrm{ng} / \mathrm{ml}$ to $36.1 \pm 6.0 \mathrm{ng} / \mathrm{ml}$. Because of the skewness of the individual changes in maximum $\Delta$ prolactin, as determined by considerable discrepancy between the mean and median changes in the maximum $\Delta$ prolactin values (mean change, $64.4 \mathrm{ng} / \mathrm{ml}$; median change, $14.1 \mathrm{ng} / \mathrm{ml}$ ), the statistical significance of the change in maximum $\Delta$ prolactin was evaluated with the Wilcoxon signed rank test. The fall in maximum $\Delta$ prolactin after thyroid hormone replacement was statistically significant, $P<0.01$. Fig. 2 also shows that at the time of the TRH test, before thyroid treatment, the mean serum $T_{3}$ and $T_{4}$ levels were both in the hypothyroid ranges, and that at the time of the TRH test, during thyroid hormone treatment, the mean serum $T_{3}$ and $T_{4}$ levels were both in the normal ranges. No sig- nificant correlations existed between the pretreatment serum $T_{3}$ or $T_{4}$ levels and the pretreatment maximum $\Delta$ prolactin responses.

Euthyroid subjects. Fig. 3 shows the mean serum prolactin response of eight normal, euthyroid subjects to the i.v. injection of $400 \mu \mathrm{g}$ TRH before treatment and during the 4 th wk of treatment with $30 \mu \mathrm{g} \mathrm{T}_{3}+120 \mu \mathrm{g}$ $\mathrm{T}_{4}$ once daily. The basal prolactin levels were $12.5 \pm 1.5$ $\mathrm{ng} / \mathrm{ml}$ before and $12.1 \pm 1.2 \mathrm{ng} / \mathrm{ml}$ during this thyroid hormone treatment. The peak prolactin levels after TRH were $41.9 \pm 4.1 \mathrm{ng} / \mathrm{ml}$ before and $39.5 \pm 3.8 \mathrm{ng} / \mathrm{ml}$ during treatment. The change in the mean pre-TRH prolactin level was not significant. Fig. 4 shows the maximum $\Delta$ prolactin for each subject before and during thyroid hormone treatment. The maximum $\Delta$ prolactin of two subjects fell by 62 and $31 \%$ respectively, but the maximum $\Delta$ prolactin of the other subjects changed by less than $9 \%$ each. The mean maximum $\Delta_{\text {prolactin levels }}$ before and during treatment were not significantly different. Serum $\mathrm{T}_{\mathbf{3}}$ levels rose a small but significant $(P<$ 0.05 ) amount during thyroid hormone treatment, but serum $T_{4}$ levels did not change significantly (Fig. 4).

Hyperthyroid paticnts. Fig. 5 shows the mean serum prolactin response of 10 patients with hyperthyroidism to $400 \mu \mathrm{g}$ TRH i.v. before and during antithyroid treatment. Before antithyroid treatment. the mean serum prolactin level was $17.0 \pm 2.0 \mathrm{ng} / \mathrm{ml}$ before $\mathrm{TRH}$ and

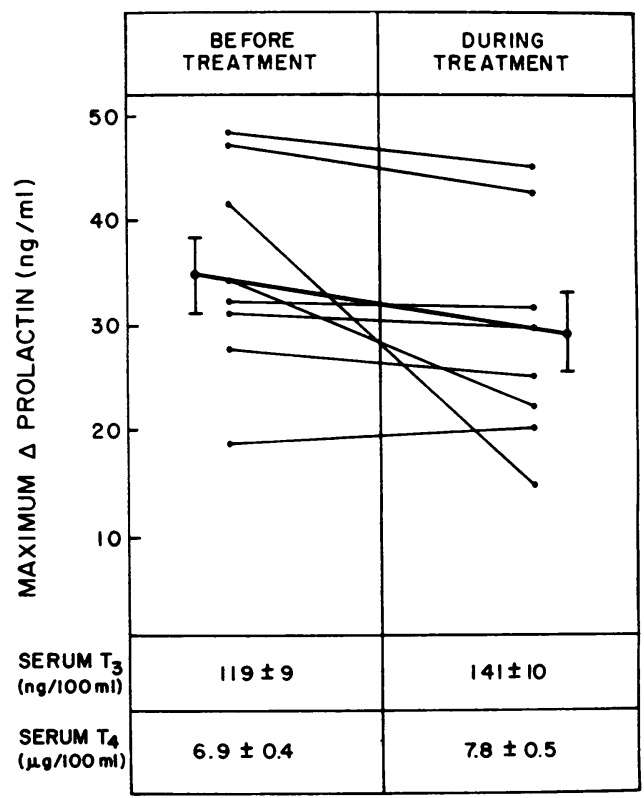

Figure 4 Effect of thyroid hormone treatment (30 $\mu \mathrm{g}$ $\mathrm{T}_{3}+120 \mu \mathrm{g} \mathrm{T}_{4}$ daily for $3-4 \mathrm{wk}$ ) on the individual maximum $\Delta$ prolactin responses to i.v. TRH in eight normal subjects. The heavy line connects the mean $( \pm S E M)$ maximum $\Delta$ prolactin responses. The mean serum $T_{3}$ and $T_{4}$ levels $( \pm$ SEM $)$ before and during treatment are also shown. 
reached a peak level of $29.7 \pm 5.1 \mathrm{ng} / \mathrm{ml} 10 \mathrm{~min}$ after TRH. After euthyroidism had been produced with antithyroid medication the mean serum prolactin level before TRH was $11.5 \pm 2.3 \mathrm{ng} / \mathrm{ml}$ and reached a peak of $51.4 \pm 8.2 \mathrm{ng} / \mathrm{ml} 10 \mathrm{~min}$ after TRH. The fall in the mean pre-TRH prolactin level was not statistically significant.

The increase in the prolactin response to TRH after antithyroid treatment was examined in greater detail by comparing the maximum $\Delta$ prolactin of each hyperthyroid subject before and during antithyroid treatment, as shown in Fig. 6. The maximum $\Delta$ prolactin was higher during antithyroid treatment in 9 of the 10 subjects. The mean maximum $\Delta$ prolactin rose from $14.2 \pm 2.9$ $\mathrm{ng} / \mathrm{ml}$ before antithyroid treatment to $46.9 \pm 6.7 \mathrm{ng} / \mathrm{ml}$ during treatment. This rise in maximum $\Delta$ prolactin was highly significant statistically, $P<0.001$. Fig. 6 also shows that at the time of the TRH test before antithyroid treatment, the mean serum $T_{3}$ and $T_{4}$ levels were both in the hyperthyroid ranges and that at the time of the TRH test during antithyroid treatment, the mean serum $T_{3}$ and $T_{4}$ levels were both in the normal ranges. The changes in maximum $\Delta$ prolactin and in serum $T_{3}$ and $T_{4}$ levels were similar in subjects treated with methimazole and in those treated with radioactive iodide. A negative correlation of borderline significance $(r=$ $-0.61, P<0.05$ ) was found between the pretreatment serum $\mathrm{T}_{3}$ levels and the pretreatment prolactin responses to TRH.

\section{DISCUSSION}

The data presented here demonstrate that the similarity between the regulation of $\mathrm{TSH}$ secretion and prolactin

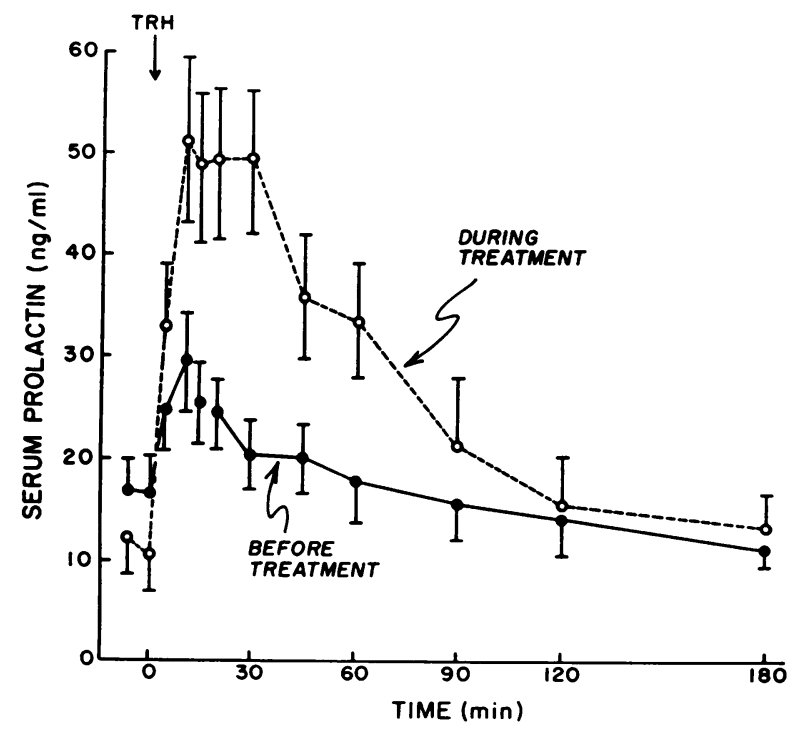

Figure 5 Serum prolactin responses to i.v. TRH before and during antithyroid treatment in 10 patients with hyperthyroidism. Means are given \pm SFM.

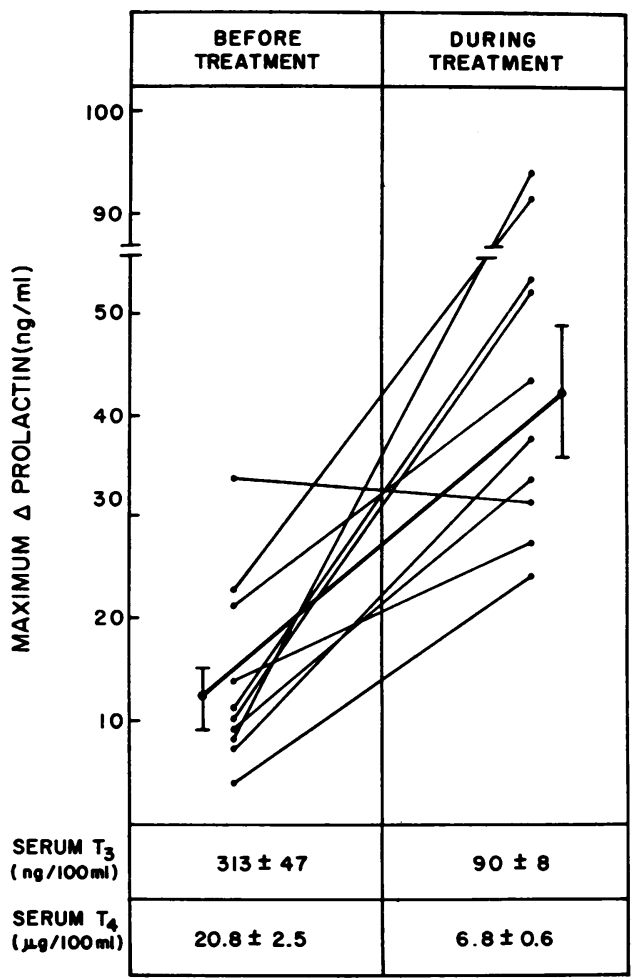

Figure 6 Effect of antithyroid treatment on the individual maximum $\Delta$ prolactin responses to i.v. $\mathrm{TRH}$ in 10 patients with hyperthyroidism. The heavy line connects the mean ( \pm SEM) maximum $\Delta$ prolactin responses. The mean serum $\mathrm{T}_{\mathrm{s}}$ and $\mathrm{T}_{4}$ levels $( \pm \mathrm{SEM})$ before and during treatment are also shown.

secretion includes not only stimulation of both hormones by TRH but also inhibition of the TRH-induced stimulation of both by thyroid hormones. The prolactin response to TRH is increased when serum $T_{3}$ and $T_{4}$ levels are below the normal ranges, as demonstrated by the significant fall in prolactin response when subjects with primary hypothyroidism were retested after they had been made euthyroid (Fig. 2). The possibility that part of this fall was due to the production of hyperthyroidism by the replacement thyroid medication was excluded by demonstrating that the prolactin response to TRH was not significantly lowered by treating normal, euthyroid subjects with the same dose of thyroid hormones as the hypothyroid subjects were treated (Fig. 4). The prolactin response to TRH is decreased when serum $T_{3}$ and $T_{4}$ levels are above the normal ranges, as demonstrated by the significant increase in prolactin response when subjects with hyperthyroidism were retested after they had been made euthyroid (Fig. 6).

Foley, Jacobs, Hoffman, Daughday, and Blizzard reported that in eight of nine children with secondary hypothyroidism, all but one case due to presumptive deficiency of endogenous TRH secretion, the prolactin re- 
sponse to exogenous TRH was also diminished by treatment with replacement thyroid medication (15). Bowers, Friesen, Huang, Guyda, and Folkers noted a similar effect in one patient with hypothyroidism secondary to a pituitary tumor and in another patient with primary hypothyroidism (1). With the exception of this last patient, changes in the prolactin response to TRH after changes in serum $T_{3}$ and $T_{4}$ levels have not been reported previously in patients with primary hypothyroidism and have not been reported at all in patients with hyperthyroidism or in normal subjects. Bowers et al. (1) found no difference between the prolactin responses in a group of 14 patients with primary hypothyroidism and those in a separate control group of 12 subjects, but responses in a group of 6 patients with hyperthyroidism were lower than those in the control group. The lack of difference between the prolactin responses of the patients with primary hypothyroidism and the control subjects was probably due to a combination of the wide variability in individual prolactin responses to TRH (6) and the use of a separate group of control subjects, rather than the use of each patient with primary hypothyroidism as his own control after thyroid replacement.

These results also show that the inhibition of prolactin secretion $y$ serum $T_{3}$ and $T_{4}$ levels differs from the inhibition of TSH by $\mathrm{T}_{3}$ and $\mathrm{T}_{4}$ in at least two respects. First, basal prolactin levels are not generally elevated in primary hypothyroidism, as are TSH levels (8). Second, TRH-stimulated prolactin release is not quite so sensitive as TSH release to inhibition by elevated levels of serum $\mathrm{T}_{3}$ and $\mathrm{T}_{4}$; TRH-induced prolactin release is not significantly affected by the treatment of normal subjects with $30 \mu \mathrm{g} \mathrm{T}_{3}+120 \mu \mathrm{g} \mathrm{T}_{4}$ daily for $3-4$ wk (Fig. 4), whereas TRH-induced TSH release is reduced by $95 \%$ by treatment of normal subjects in this way (4).

The data presented here do not elucidate the mechanisms by which TRH stimulates prolactin release and by which thyroid hormones inhibit this effect. It is tempting to make an analogy to the TRH-TSH-T, $\mathrm{T}_{4}$ axis and to assume that TRH directly stimulates the pituitary to secrete prolactin and that $T_{3}$ and $T_{4}$ directly inhibit this pituitary secretion. The results presented here, however, are not evidence for or against this hypothesis or for or against the possibility that an intermediary hypothalamic factor, a prolactin-releasing hormone, is involved. The data on TRH-induced prolactin release in subjects with hypothyroidism due to pituitary $(1,16)$ or hypothalamic $(15,17)$ disease likewise do not help to elucidate the mechanisms by which TRH stimulates prolactin release and thyroid hormones inhibit this stimulus.

An intermediary role for TSH in TRH-induced prolactin release does appear to be excluded, however, since normal subjects treated with $30 \mu \mathrm{g} \mathrm{T}_{3}+120 \mu \mathrm{g} \mathrm{T}_{4}$ had a normal prolactin response to TRH (Fig. 4), even though this treatment virtually abolishes TSH release (4). The finding of a patient with isolated TSH deficiency and no TSH response to TRH but a substantial prolactin response (16) also appears to exclude an intermediary role for TSH.

We conclude that changes from normal serum levels of $T_{3}$ and $T_{4}$ are associated with changes in prolactin responses to TRH; subnormal serum levels of $T_{3}$ and $T_{4}$ increase TRH-induced prolactin release, whereas substantially higher than normal serum levels of $T_{3}$ and $T_{4}$ inhibit this release. The mechanisms by which these effects occur are as yet unknown.

\section{ACKNOWLEDGMENTS}

We thank Michael S. Anderson, M.D., Abbott Laboratories, for generous supplies of TRH; Maria M. Rabelo, M.D., for assistance in patient care; Francis H. Sterling, M.D., for referral of patients with hypothyroidism; Miss Cordelia Shute and her staff of the Clinical Research Center, Hospital of the Lniversity of Pennsylvania, for dedicated performance of the in vivo studies; Mrs. Maryanne O'Neill and Miss Leona Scott, for painstaking technical assistance; and Mrs. Elaine Paolini, for careful secretarial assistance.

This work was supported by U. S. Public Health Service research grants AM-14039 and AM-05105, training grant AM-05649, and Clinical Research Center grant RR-40 from the National Institutes of Health, U. S. Public Health Service.

\section{REFERENCES}

1. Bowers, C. Y., H. G. Friesen, P. Hwang, H. J. Guyda, and K. Folkers. 1971. Prolactin and thyrotropin release in man by synthetic pyroglutamyl-histidyl-prolinamide. Biochem. Biophys. Res. Commun. 45: 1033.

2. Jacobs, L. S., P. J. Snyder, J. F. Wilber, R. D. Utiger, and IV. H. Daughaday. 1971. Increased serum prolactin after administration of synthetic thyrotropin releasing hormone (TRH) in man J. Clin. Endocrinol. Metab. 33: 996 .

3. L'Hermite, M., L. Vanhaelst, G. Copinschi, R. LeClercy, J. Golstein, O. D. Bruno, and C. Robyn. 1972. Prolactin release after injection of thyrotropin-releasing hormone in man. Lancet. 1: 763 .

4. Snyder, P. J., and R. D. Utiger. 1972. Inhibition of thyrotropin response to thyrotropin-releasing hormone by small quantities of thyroid hormones. J. Clin. Iniest. $51: 2077$.

5. Snyder, P. J., and and R. D. Utiger. 1972. Response to thyrotropin releasing hormone (TRH) in normal man. J. Clin. Endocrinol. Metab. 34: 380.

6. Jacobs, L. S., P. J. Snyder, R. D. Utiger, and W. H. Daughaday. 1973. Prolactin response to thyrotropin releasing hormone in normal subjects. J. Clin. Endocrinol. Mctab. 36: 1069.

7. Lieblich, J. M., and R. D. Utiger. 1972. Triiodothyronine radioimmunoassay. J. Clin. Invest. 51: 157.

8. Odell, W. D., J. F. Wilber, and R. D. Utiger. 1967. Studies of thyrotropin physiology by means of radioimmunoassay. Recent Prog. Horm. Res. 23: 47.

9. Jacobs, L. S., I. K. Mariz, and W. H. Daughaday. 
1972. A mixed heterologous radioimmunoassay for human prolactin. J. Clin. Endocrinol. Metab. 34 : 484.

10. Lewis, U. J., R. N. P. Singh, and B. K. Seavey. 1971. Human prolactin: isolation and some properties. Biochem. Biophys. Res. Commun. 44: 1169.

11. Murphy, B. E. P., and C. J. Pattee. 1964. Determination of thyroxine utilizing the property of protein-binding. J. Clin. Endocrinol. Metab. 24: 187.

12. Snedecor, G. W., and W. G. Cochran. 1967. The comparison of two samples. In Statistical Methods. Iowa State University Press, Ames, Iowa. 6th edition. 91.

13. Snedecor, G. W., and W. G. Cochran. 1967. Shortcut and non-parametric methods. In Statistical Methods. Iowa State University Press, Ames, Iowa. 6th edition. 128.

14. Snedecor, G. W., and W. G. Cochran. 1967. Correlation. In Statistical Methods. Iowa State University Press, Ames, Iowa. 6th edition. 172.
15. Foley, T. P., Jr., L. S. Jacobs, W. Hoffman, W. H. Daughaday, and R. M. Blizzard. 1972. Human prolactin and thyrotropin concentrations in the serums of normal and hypopituitary children before and after the administration of synthetic thyrotropin-releasing hormone. J. Clin. Invest. $51: 2143$.

16. Sachson, R., S. W. Rosen, P. Cuatrecasas, J. Roth, and A. G. Frantz. 1972. Prolactin stimulation by thyrotropinreleasing hormone in a patient with isolated thyrotropin deficiency. N. Engl. J. Med. 287: 972.

17. Kaplan, S. L., M. M. Grumbach, H. G. Friesen, and B. H. Costom. 1972. Thyrotropin-releasing factor (TRF) effect on secretion of human pituitary prolactin and thyrotropin in children and in idiopathic hypopituitary dwarfism: further evidence for hypophysiotropic hormone deficiencies. J. Clin. Endocrinol. Metab. 35: 825. 